\title{
VELIKI RAT - VELIKE PROMJENE: ČITANJE PROMJENA SLIKE VOJNE UNIFORME
}

\author{
ANTE TONČI VLADISLAVIĆ \\ CIMO - Centar za istraživanje mode i \\ odijevanja \\ 10000 Zagreb, Mesnička 1 \\ tonci.vladislavic@gmail.com
}

DOI: $10.17234 /$ SEC.28.12

Prethodno priopćenje

Primljeno: 9. 5. 2016.

Prihvaćeno: 10. 6. 2016.

Ovaj rad nalazi se u otvorenom pristupu i može se distribuirati u skladu s odredbama licencije CC BY-NC-ND 4.0 HR

Rad se bavi izgledom i reprezentacijom vojnih uniformi, koje u Prvom svjetskom ratu postaju neizbježan $i$ standardiziran ratni atribut. One su postale važan dio ratne ali i ukupne odjevne slike. Promjene ratnih uniformi istiskuju dotadašnju viziju uniforme i njezinu kodiranost, proizvodeći popunjavanje značenjskog prostora novim kodovima, a mogu se čitati na razini uniforme kao objekta, ali još više u retorici fotografske slike. Napredak industrijalizacije $i$ masovne proizvodnje standardiziranih vojnih uniformi poklapa se s industrijom stvaranja $i$ reproduciranja slike (fotografije) u tiskanim masovnim medijima, pa se sve informacije o promjenama uniforme čitaju kao promjene kodiranosti fotografske reprezentacije. Radom se želi pokazati vidljivim promjene koje su se dogodile u razvoju vojne uniforme kao objekta, kao i promjene kodiranosti unutar reprezentacije fotografske slike. ${ }^{1}$

Ključne riječi: Prvi svjetski rat, odijevanje, vojne uniforme, retorika fotografske slike, reprezentacije u fotografskoj slici

\section{UVOD}

Uniforme u Prvom svjetskom ratu postaju neizbježan i standardiziran ratni atribut. One su postale važan dio ratne ali i ukupne odjevne slike koja čini vidljivim kako "pojavnost zamjenjuje stvarnost” (Wilson 2003:33).

\footnotetext{
${ }^{1}$ Ovaj rad predstavlja dio većeg istraživanja koje i dalje traje, a bavi se vojnim uniformama, izgledom i značenjem kao oblicima odjevne i reprezentacijske slike. Unutar CIMO-a - Centra za istraživanje mode i odijevanja, provodi se istraživanje i znanstveni rad na projektu Muški manifest: konstrukcija stereotipa i reprezentacija "muških fantazija" - odijevanje, izgled, tipologija i oblici društvenog funkcioniranja muške moći u doba jugoslavenskog socijalizma. Projekt istražuje i problematizira odnos mode i odijevanja
} 
Kakva je ta pojavnost koja zamjenjuje i preuzima sliku stvarnosti nudeći se kao stvarnost sama? Pogled okrenut promjenama izgleda vojnih uniformi uoči i za vrijeme Velikog rata $^{2}$ iz današnje perspektive prilog je čitanju vizualne komunikacije fotografije popraćen citatima iz literature. Fotografska slika, kao i tekstualni citati, a s perspektivnom distancom od stotinjak godina, omogućuju čitanje koje čini vidljivim dvije različite kategorije vojnih uniformi, potvrđujući kontrast i veliku reprezentacijsku razliku u izgledu, pojavnosti i reprezentaciji uniformi koja se dogodila s pripremama za događaje Prvoga svjetskog rata i kasnije.

U ovom se istraživanju analizira fotografski materijal gdje je pristup čitanju određen načinima suvremene vizualne kulture. Slika odjednom sintetizira ukupnost, i narativ i značenje: za čitanje fotografije potreban je pristup slici kao reprezentacijskoj, ali i kao vizualnom dokumentu i prijenosniku slike predmeta određenog trenutka jer "u Fotografiji nikada ne mogu nijekati da je predmet bio tamo" (Barthes 2003:98). "Postoji dvostruka povezana pozicija: stvarnost i prošlost” (Ibid.), koje u analitičkom procesu uključuju mogućnosti i načine novog viđenja rekonstrukcije događaja i vremena. Pitanja o uvjetima i motivima nastanka slike, a koji nisu jednaki u tretiranju i reprezentiranju uniformi prije ili za vrijeme Velikog rata, pomiču perspektivni pogled prema samom procesu snimanja i boljem razumijevanju i rekonstruiranju promjena vremena te promjena medija $\mathrm{i}$ funkcije fotografije. Fotografije korištene kao studije slučaja u istraživanju, dio su privatne zbirke i fotoalbuma domaće provenijencije i odnose se na razdoblje kraja 19. i početka 20. stoljeća, kao i na razdoblje samoga Velikog rata. $^{3}$

gdje je značajan dio posvećen uvođenju i reprezentaciji muških vojnih uniformi - s akcentom na vizualnoj retorici fotografske slike.Više o projektu Centra: http://www.cimo. $\mathrm{hr} / \mathrm{hr} /$ projekti/2014/muski-manifest-konstrukcija-stereotipa-i-reprezentacija-muskihfantazija-odijevanje,-izgled,-tipologija-i-oblici-drutvenog-funkcioniranja-muke-moi-udoba-jugoslavenskog-socijalizma-*.html (pristup 26. 9. 2016.).

${ }^{2}$ Veliki rat uvijek se odnosi na Prvi svjetski rat, od 1914. do 1918. godine.

${ }^{3}$ Privatna zbirka fotografija uključuje mnoštvo pojedinačnih analognih, uglavnom amaterskih fotografija, kao i dva albuma fotografija neidentificiranog vlasnika koje dokumentiraju njegov boravak na svim važnijim bojišnicama Velikog rata, od Galicije do Italije (postoji pretpostavka da je vlasnik i glavni protagonist na fotografijama izvjesni Ivan Vincetić, a što će biti potrebno istražiti). Vlasnik zbirke jest autor ovog teksta. 
Osim fotografske slike kao evidencije, $\mathrm{u}$ istraživanju i elaboriranju izgleda i prikazivanja vojnih uniformi u ovom su razdoblju korišteni neki tekstovi, uglavnom citati iz autobiografskih zapisa, koji nude analitičke deskripcije (Graves 2010; Kolander 1914), a uz njih su korišteni i "literarizirani" opisi (Blom 2015; Broh 1982a, 1982b; Gombrowicz 2014) koji su tekstualno opisivanje jednog zamišljaja koji dodaju onaj tako potreban bijeg u imaginaciju i otkrivanje nevidljivoga.

\section{VOJNE UNIFORME: OD VIŠEBOJNOG ŠARENILA DO FUNKCIONALNE PRILAGODBE}

19. je stoljeće doba velikih društvenih, političkih, tehnoloških i ekonomskih promjena, označeno brojnim vojnim konfliktima i ratovima, kako u Europi tako i Americi. S druge strane, ono je označeno ubrzanim razvojem industrije na svima planovima, tako i u proizvodnji odjeće i uniformi karakteriziranim specifičnim funkcionalnim zahtjevima. Postoji jasna dvostrana relacija između ratnih zahtjeva i investiranja u razvoj tekstilno-odjevne industrije. Isto tako, ovo je stoljeće doba značajnih tehničkih inovacija, među njima i pojave proizvodnje fotografije kao novog medija, kojom se evidentira društveni kontekst, a koji će se pokazati plodonosnim za dalekosežne kulturalne implikacije.

Razvoj odijevanja (i mode) kroz "povijest otkriva različitost ritmova njihovih izmjenjivanja" (Cvitan-Černelić et al. 2002:11), a koje se odvijalo u većim ili manjim ciklusima koji su donosili velike odjevne promjene koje vidimo kao mjeru i sliku društvenih, političkih, ekonomskih i rodnih promjena. Smatra se da je sveukupna odjevna (i modna) povijest označena velikom i prijelomnom promjenom u drugoj polovini 14 . stoljeća, kao početkom nastanka same mode "kojom se jasno razdvajaju gornji i donji dio tijela", dok u teoriji mode danas "skloniji smo pojavu mode smjestiti u kontekst preobrazbi okvira života i društva tijekom 19. stoljeća, uvjetovanim razvojem industrijalizacije" (Ibid. 12). U takvom kontekstu, moda i odijevanje postaju materijalni i simbolički materijal bogat znakovima i simbolima koji nam otkrivaju mnoštvo slojeva, vidljivih i onih manje vidljivih, a koje tek treba otkrivati i očitavati.

Te velike promjene u odijevanju u 19. stoljeću, potpomognute zamahom razvoja masovne, industrijski organizirane proizvodnje 
standardiziranih odjevnih predmeta, a gdje se smanjuje udio ručnog rada, dugujemo izumu šivaćeg stroja koji omogućuje mehanizaciju proizvodnje.

Šivaći stroj, usavršen 1829. od Barthélemyja Thimonniera, stvorio je pravu paniku među krojačima koji su se pobunili i uništili 80 strojeva u tvornici uniformi Germain Petit [...] Oni se nisu (ponovno) okupili u tvornicama sve do 1880-ih, i to jedino primjetno u industrijskoj koncentraciji u vojnim radionicama (Perrot 1994:67).

U ovoj fazi praćenoj patentiranjem i daljnjim usavršavanjem šivaćeg stroja, novi, napredni oblici industrijske proizvodnje odjeće proizlaze i iz nove društvene situacije. "Tim su preobrazbama i stvorene osnovne pretpostavke za uspon, razvoj i difuziju mode, koja postupno prelazi granice okvira odijevanja i uvlači se u sve pore suvremena života." (Cvitan-Černelić et al. 2002:12). U takvom kontekstu, u odjevnoj slici evidentiramo izrazite klasne i rodne razlike. "Moda nikada nije toliko rigorozno podijelila spolove kao u 19. stoljeću" (Vinken 2005:5). Što se tiče muškarca, razvoj modne slike možemo pratiti kroz investiranje u novi, "građanski" odjevni izgled gdje dolazi do svojevrsne redukcije, svodeći ga na trodijelno, sivo ili crno odijelo, koje na svojevrsni način uspostavlja "uniformirani” izgled muškarca u gradu. "Kako komentiraju brojni pisci, bijaše to početak stila odijevanja, u kojem se neposredno očitovala neutralnost - dakle, neisticanje u odnosu na druge" (Sennett 1989:213), što je imalo implikacije na individualnom planu (pitanje maskulinosti) kao i implikacije na planu društvene slike. Tako Barbara Vinken smatra da je "19. stoljeće okarakterizirano kao stoljeće 'odricanja od maskulinosti' [termin preuzet od Johna Carla Flügela, op. a.], a koje se sastoji od toga da se muškarac odriče mode prisvajajući jednostavnu retoriku ne-retoričnosti” (Vinken 2005:11). Usporedno, ili unatoč ovoj redukciji u izgledu građanskog odijela, u 19. stoljeću, uporno i "ponovno je tu 'dvor' koji inzistira na uvođenju aristokratske reprezentativne slike maskulinosti, kao historijskog viška i relikta jednoga davnog vremena, u građanske uniforme, čiji se sjaj danas čini kao kuriozum (...) Ove uniforme predstavljaju relikt carskog, i u najužem smislu, pred-modernog i predmodnog, ne-buržujskog razdoblja života" (Ibid.).

Možemo, dakle, na planu muškog odijevanja, pratiti napetost između dva različita aspekta odjevnih praksi: jedan nalazimo u konceptu 
trodijelnoga tamnog odijela, a s druge strane ostaje prisutno nostalgično inzistiranje na svakodnevnoj upotrebi "uniforme relikta", uz jaku prisutnost raskošnih ornamentalnih dekoracija, heraldičkih oznaka i izrazito šarenilo intenzivnih boja. Ovo inzistiranje na kontinuitetu dvorske aristokratske prezentacije postaje anakrono, tim više što je 19. stoljeće, kao stoljeće ratova, moralo razvijati masovnu ponudu novih, funkcionalnih vojnih uniformi.

"Ratovanje je u 18. i 19. stoljeću bilo raznobojan poslovni pothvat britanski crveni kaputi, austrougarske bijele tunike, švedske plave i žute. Ovo je bilo u redu dok su vojske vojevale mačevima" (Dunn 2009:12). No postupno će šarenilo intenzivnih boja biti potiskivano u korist funkcionalnih promjena prema manje vidljivoj, mimikrizirajućoj kaki boji koju u europsku vojnu praksu uvode Britanci. "Britanci su nosili kaki boju od indijskog ustanka 1857. godine" (Ibid.).

Uglavnom se smatra da ovakvo dekorativno naglašavanje distinkcija dugujemo Napoleonovim ratovima iako u kasnijim mirnodopskim vremenima možemo evidentirati inzistiranje na daljnjem dodavanju ukrasa i simbola aristokratske pripadnosti monarhijskoj hijerarhiji. Neki rodovi nacionalnih vojski predstavljaju kolekcije bogato dekoriranih uniformi koje su uzore nalazile u većini europskih careva i njihove dvorske svite, kao npr. Wilhelm II., Franjo Josip I., Napoleon III., a održale su se, barem kao "paradne" uniforme, sve do početka Prvoga svjetskog rata (1914.) koji je označio kraj šarenila vojnih uniformi.

U našim krajevima također nalazimo "šarene" uniformne matrice pripadnosti Austro-Ugarskoj Monarhiji, tj. Austrijskom Carstvu i Ugarskoj Kraljevini (1867.-1914.). Opise o jarkim bojama koje su označavale pripadnost vojnim rodovima nalazimo u knjizi Tomislava i Višeslava Aralice Hrvatski ratnici kroz stoljeća (1996.) gdje za konjanike stoji da je

konjaništvo, kao elitna postrojba, zadržalo ukrašene odore žarkih boja. Jedini ustupak nečemu što se može nazvati maskiranjem, bilo je 1913. uvođenje navlaka za čakoe (kape), štukastosive boje (...) Ulanska pukovnija dočekuje početak Prvog svjetskog rata u odorama jedinstvenim za sve ulanske pukovnije zajedničke vojske: imali su plavu dolamu s crvenim obrubima te crvene hlače širokog kroja (...) a kod vojnika su postojale dvije vrste odora: paradna i pohodna. 
Paradnu odoru pripadnika zajedničke vojske ugarskog pješaštva činile su svijetloplave hlače, ukrašene gajtanom crno-žute boje, tamnoplava bluza i tamnoplavi paradni čako (vrsta kape) (Aralica i Aralica 1996:198-204).

Silni ratni sukobi, često u područjima daleko od mjesta proizvodnje i mogućnosti dostave (indijska pobuna protiv Britanaca, 1857.-1859.; Krimski rat, 1853.-1856.; Američki građanski rat, 1861.-1865.; Burski rat, 1899.-1902., itd.), stvaraju potrebu za velikim količinama prikladnih, funkcionalnih vojnih uniformi i opreme, što će dovesti do planiranja proizvodnje i investiranja u nove oblike i razvoj organizacije proizvodnje koja se omasovljuje uz standardiziranje veličina, budući je uniforma bila namijenjena anonimnom vojniku.

Koliko su god početne potrebe bile pokrivane proizvodnjom "po mjeri” ili u omanjim tvornicama, ključni povijesni preokret u drugačijem poimanju funkcije odore i masovnosti proizvodnje veže se uz Američki građanski rat. "Najvažniji elementi u ovoj transformaciji jesu šivaći stroj, krojevi za specifične modele, kao i razvoj preciznog sustava tjelesnih mjera" (English 2013:66). Autorica Crane smatra da je upravo "razmjernik tjelesnih mjera, a time i skala veličina omogućila izvedivost proizvodnje gotove odjeće u masovnim razmjerima" (Crane 2000:74-75). Povećane potrebe ekspandiraju "naročito za vrijeme Američkoga građanskog rata kada je postojala potreba za tisućama gotovih uniformi" (English 2013:66). No potrebe u neizmjernim količinama, a zahvaljujući unaprijeđenim oblicima masovne proizvodnje, pozadinski su pratile sve ratne događaje i u Europi gdje su "prve standardizacije i mjerenja izvedena na vojnicima pruske vojske. Vojna normiranja i standardizacije ljudskog tijela prema veličinama - samo četiri veličine - predstavljaju sine qua non konfekcijske (prêt-à-porter) industrijske proizvodnje" (Vinken 2005:12).

Posljedično, sve veća i dobro organizirana proizvodnja vojnih uniformi utjecala je i na proizvodnju ostale (modne) odjeće zato što su, mnogo prije negoli je industrijska proizvodnja izmislila masovnu proizvodnju, tj. prêt-à-porter, vojne uniforme već uspostavile upotrebu standardizacije. "Dimenzije odjeće rađene po mjeri pripadaju (...) carstvu odjeće, tj. individualnoj dimenziji jezika (...) dok veličinski brojevi 
grupiraju tijela u standardizirane. kategorije" (Patrizia Calefato, u Bonami et al. 2000:196).

Svakodnevni je život zapuhnut rezultatima proizvodnje, distribucijom i dostupnošću robe na tržištu, kao i sve većim klasnim podjelama. Jaz između onih koji ostvaruju i onih koji gospodare viškom vrijednosti sve je veći. "Vrtoglave godine" (Blom 2015) od 1900. do 1914., tj. do početka Prvoga svjetskog rata, označene su izrazito velikim promjenama i vidljivim "raspadom vrijednosti" (Broh 1982b).

Ne treba zanemariti manje vidljivu ali evidentiranu, količinsku, time i značajnu ekonomsku dimenziju (ratne) proizvodnje. "Izrada uniformi, kao i sigurnost dobrih vojnih ugovora, pogodovali su razvoju biznisa, tako da je na kraju Velikog rata, kada je odjednom 4 milijuna trebalo civilno odijelo, Burton bio u stanju ispuniti ovakav zahtjev" (Waddell 2004:78). Sve je to utjecalo na mijenjanje odjevnih karakteristika uniformi, kako u ergonomskoj funkciji tako i u izgledu. Postupno smanjivanje dekoracija i oznaka vodi prema redukciji vizualne pojavnosti uniformirane osobe, pa se individualnost, status, vojni rang i pripadnost rodovima zamjenjuje sitnijim, lako zamjenjivim oznakama, ili kolorističkim detaljima na ovratnicima, a sve u prilog mimikrijskom prikrivanju. "Iznad samih tehničkih mjera što ih pruža ujednačenost uniformi, uniforme nude bogatstvo referencija u raznolikosti i u kombinacijama" (Vinken 2005:12), što za čitanje slike vojnih uniformi predstavlja dragocjeni materijal. Bogatstvo referencija govori da "osobe u vojnoj uniformi moraju biti 'semiotički eksplicitne' (...) a govore o pripadnosti rodu vojske, oznakama ranga i vojne hijerarhije, tako da je kompleksna semiotička funkcija uniforme evidentna, sa svojom bogatom raznolikošću znakova i simbola koji komuniciraju (...) visoko detaljne informacije" (Lorenzo Greco, u Bonami et al. 2000:147-148).

\section{STOLJEĆE - UNIFORME KAO POVIJESNI RELIKT}

Početkom 20. stoljeća izgled vojne uniforme potvrđuje izrazitu redukciju smanjujući retoričnost (izgleda), i to "u opsegu kojim se [on] odriče mode i prihvaća simplificiranu retoričnost anti-retoričnosti, a zadobiva identitet, autentičnost, neupitnu maskulinost, ozbiljnost" (Vinken 2005:11). Time on iskazuje distanciranje od jednog načina vojničkog "osjećanja" koje se uspostavilo, pokušavajući da zadrži uniformu-relikt 


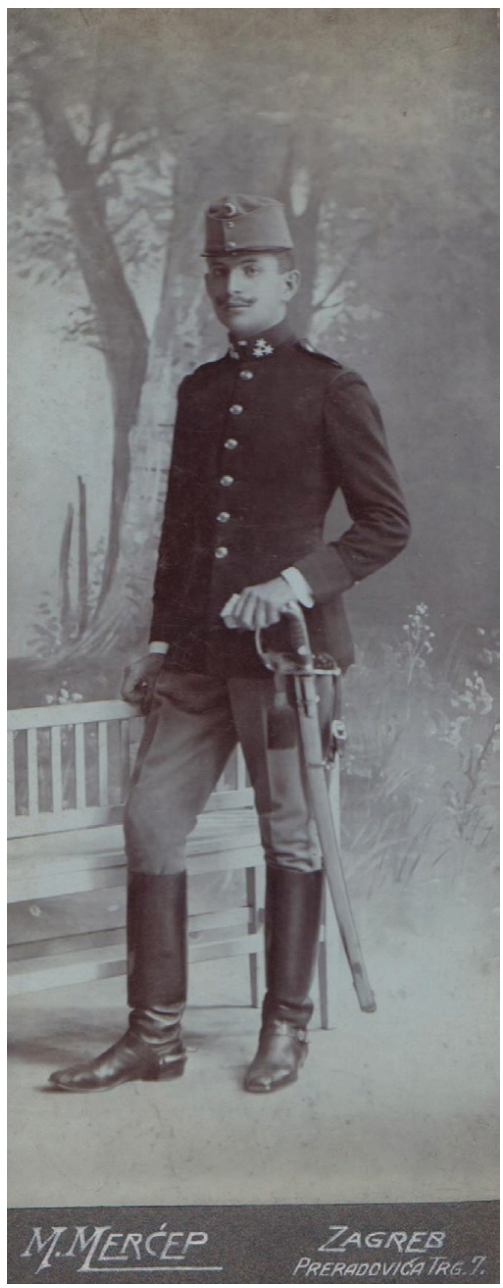

Slika 1: Muškarac u uniformi, fotograf: Atelier Merćep, Zagreb, oko 1900.

kao odjevni romantični koncept. Broch u trilogiji Mjesečari, u prvom dijelu (1888. Pazenovili romantika), na nekoliko stranica s posebnom pozornošću govori o poručniku Von Pasenowu i njegovoj uniformi:

... ona je kao neka tvrda futrola (...); pravi zadatak uniforme i jest u tome da pokaže i ustanovi poredak u svetu $\mathrm{i}$ da potre sve rasplinuto i razliveno $\mathrm{u}$ životu, onako kao što skriva sve što je rasplinuto i mekušasto na čovečjem telu (...) zatvoren u svojoj tvrđoj futroli, zakopčan remenjem i kukicama" (Broh 1982a:60).

Brochov tekst omogućuje da postane lakše vidljivim sve ono što tom svijetu pripada, kao i odnosu prema uniformi, a time olakšava pristup retorici koja se čita na fotografijama iz epohe. ${ }^{4}$

Broch u svom tekstu, osim izgleda i značenja uniformi, problematizira i stanje duha, naglašavajući time snažnu vezu između vojne uniforme, vojnog tijela i vojničkog duha, što se poklapa i s retorikom samih fotografija:

A kako je uvek romantično kad se zemaljsko uzdigne do apsolutnoga, to je stroga i prava romantika ovoga doba romantika uniforme,

kao da postoji neka vanzemaljska i vanvremenska ideja uniforme, ideja koja ne postoji, a koja je ipak toliko jaka da uniformisanog čoveka čini ludim za uniformom (Broh 1982a:61).

\footnotetext{
${ }^{4}$ Priložene fotografije domaćih fotografa s početka stoljeća, snimane u studiju, služe kao ilustracija sličnosti izgleda muškaraca u uniformama zato što su jednake fotografijama iz cijele tadašnje srednje Europe.
} 
No to govori i o jednoj manje vidljivoj dimenziji (psihoanalitičke) pozadine takvog odnosa prema toj vrsti "uniforme relikta":

Joahim zato nije voleo da u vojničkoj sobi zatiče ljude sa raskopčanim bluzama; bilo je u tome nešto nepristojno (...) Joahim se većinom i sam mašao za dugmeta na sopstvenoj bluzi i osećao se bezbedan i miran tek kad bi se uverio da su sva zakopčana (Ibid.).

To isto tako govori o kolektivnoj slici i društvenoj atmosferi u kojoj postoji mogućnost da red i poredak stvari krenu u smjeru bez osobne kontrole: "Jer stravično je bilo pomisliti da svako pod bluzom nosi to svima zajedničko oličenje anarhije" (Ibid. 62).

Ovakva "uniforma relikt" jest okvir, poredak stvari kao i spas od straha od "prelijevanja" (skuti košulje, manžete košulje i sl.). To je okvir koji fiksira i kontrolira, osigurava nepromjenjivost i zadržavanje daha, a rješenje nalazimo u samom kroju i obliku uniforme koja je maksimalno ukrojena nizom ušitaka, tijesna, zakopčana, koja prisiljava na uspravnost, jasnost građe muškog tijela, pozu i gestu; ona je okvir za tijelo i duh, futrola, što "istina nije davalo sadržinu, ali mu je davalo stav" (Ibid.), i to ne bilo koji nego pravo (i umišljaj) pripadnosti sjećanju na aristokratski, dvorski, monarhijski okvir. Ova velika doza romantičarskog osjećanja slijepa je za silne i brze promjene, jer "kad se netko od svoje desete godine navikne da nosi uniformu (...) nije onda više kadar odrediti gdje se nalazi granica između njegovog Ja i uniforme" (Ibid. 63). Ova vrsta uniforme predstavlja futrolu, okvir koji čuva poredak stvari.

Ovo se poklapa s retorikom samih fotografija, kako prema van (javnosti), isto tako prema unutra (privatnosti) - sama pojavnost, slika izvanjske poruke, čita se kao gusta vizualna naracija, kao vidljivi višak retoričnosti; prema unutra, a to je barem jednako važna funkcija uniforme, uniforma je kontrola, bolje rečeno samokontrola, da se nigdje ne pojavi nešto iracionalno, ili čak anarhično, što ugrožava poredak (drugi dio Brochove trilogije nosi naslov 1903. Ěs ili anarhija). Jasno je koliko oklopni oblik, izgled, stas i stav markiraju oštru i jasnu granicu između uniformiranog tijela i okolice: objekt snimanja jasno je izdvojen u iluzioniranom pejzažu fotografskog studija, ostavljen vlastitoj narcističkoj i romantičkoj projekciji sebe kao singularnosti u moru novih promjena i mnoštvu novih pluralnosti. 


\section{FOTOGRAFSKA SLIKA: PROMJENE PROIZVODNJE, DISEMINACIJE I GLEDANJA}

Promjenestvarnostividljivesukao promjeneuvizualnoj reprezentaciji, a fotografija se tu javlja kao alat evidentiranja i kao trajni prijenosnik, kao dokumentaristički korpus, svojevrsni arhiv i trajni interpretativni medij. Pojava fotografije nije odmah imala neko posebno značenje i trebalo je dosta vremena da kritičarima postane "jasno da je mogućnost da se uhvati trenutak ono najvažnije. Fotografija je bila ključni alat za snimanje i opis različitog vremena između promatrača i objekta." (Mirzoeff 1999:70). Fotografska je slika bilježila objekt u trenutku, a za promatrača to postaje snažan, dostupan prijenosnik slike i vizualne poruke. "U stvarnom osjećaju, prošlo je vrijeme postalo dostupno jednako kao svaka druga roba." (Ibid. 71-72). Naime, mogućnost masovne industrijske proizvodnje i reprodukcije fotografske slike, njezina dostupnost i utjecaj, usporedivi su s procesima masovne industrijske proizvodnje bilo koje robe na tržištu.

U svojoj knjizi Zašto je fotografija važna, autor Jerry L. Thompson, i sam fotograf, kaže kako je "fotografija važna zbog dva razloga: prvo, kako fotografija radi, ne samo kao umjetnički nego i kao epistemološki medij; drugo, ona predstavlja jedan instruktivni primjer nečeg što može biti njezino razumijevanje danas" (Thompson 2013:4).

Za pitanje gledanja fotografije danas, nalazimo primjenjiv naputak u knjizi Svijetla komora, gdje Barthes za pristup fotografiji nudi nekoliko selekcijskih kriterija kroz "podjele kojima je podvrgnuta, koje su ili empirijske, (...) ili retoričke (...) ili estetičke" (Barthes 2003:8). U slučaju čitanja slike vojnih uniformi, retorička metoda može pomoći da se lakše učine vidljivima reprezentacijske razlike uniformi.

Fotografija uvijek nešto evidentira, ona je evidencija objekta i vremena (snimanje), ali je isto tako i prijenosnik reprezentacije (pojavnosti) i podloga za diseminaciju (masovni mediji), a time i za dostupnost $\mathrm{i}$ čitanje slike. Razvoj tehničkih i tehnoloških mogućnosti, kao i povijesni kontekst velikih događaja, urodio je stalnim rastom broja nastalih fotografija i važnošću posredovane poruke. Odnos prema fotografiji, s jedne strane, promatramo s uvažavanjem (analizom, konstatacijom) u trenutku njezina nastanka, kao i u različitim funkcijama komunikacijske razine proizvedene slike. Poslije samog snimanja slike, slijedi mogućnost 
beskonačne multiplikacije fotografije iz negativa (proizvodnja slike), s jedne strane, i njezina mogućnost medijske diseminacije (reprodukcije), a time njezina vidljivost i komunikativnost preko masovnih tiskanih medija. Već je početkom 19. stoljeća upotreba litografije značila velik korak jer “je omogućila grafici da ilustrira svakodnevicu. Počela je ići ukorak s tiskom. Međutim, već nekoliko desetljeća nakon izuma litografije natkrilila ju je fotografija" (Benjamin 1986:127). Dostupnost fotografske slike u javnosti i njezin utjecaj ovisit će upravo o mogućnostima reprodukcije i razvoju tiskovnih medija.

\section{FOTOGRAFSKA EVIDENCIJA UNIFORMI U STUDIJU}

U samim počecima fotografija često prikazuje uniformiranog pojedinca koji odlazi fotografu u studio gdje se realizira poziranje i snimanje. Takva je realizacija fotografije određena planiranom namjerom stvaranja slike kao želje da se objekt trajno obilježi kanoniziranim pristupom u ritualiziranom postupku: fotograf i model nalaze se u studiju. Oni tu ostvaruju dogovorni odnos, neki oblik konvencije kojom model, muškarac u uniformi, želi ovjekovječiti, uvjetno rečeno, “lijepu”, romantičnu sliku, što i jest u naravi takvoga, uniformiranog muškarca: uniforma za njega predstavlja vrlo precizan kodni sustav koji ne smije biti iznevjeren, pa čin fotografiranja pretpostavlja poziranje kao narcistički odgovor na izazov objektiva, a sve u konstruiranju romantične slike, kao trajne. "Još podsjeća oprema tih portreta sa svojim postamentima, balustradama i ovalnim stolićima na vrijeme, kada se zbog dugog trajanja ekspozicije modelima moralo dati potpornje da se ne miču" (Ibid. 157).

Fotografiranje u takvoj vrsti uniforme u studiju postaje oznaka građanskog statusa, standarda, ukusa, pa zabilješka o pojedinačnom identitetu postaje tipska za ukupnu sliku vremena, ali samo kao zbroj, niz pojedinačnih fotografskih vrlo sličnih slika. Ovakav niz pojedinačnih slika stavljenih zajedno predstavljao bi oblik društvenog albuma koji ne reprezentira slojevitu sliku vremena nego predstavlja samo niz pojedinačnih evidencija, niz "biografema” (Barthes 2003:39). 


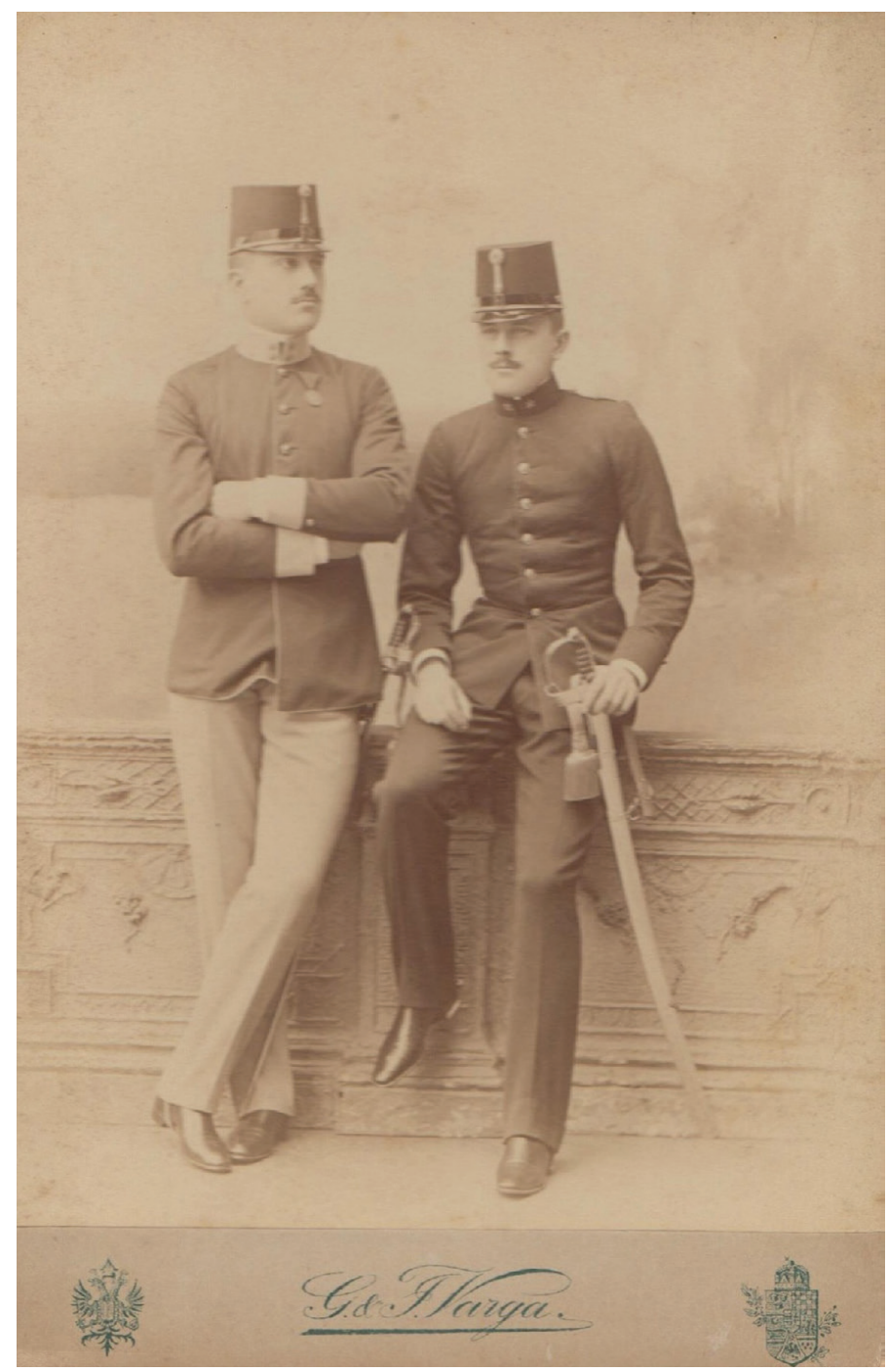

Slika 2: Dva muškarca u uniformama, fotograf: Atelier Varga, Zagreb, oko 1900.

Ono što je na studijskim fotografijama očito jest ta unaprijed osigurana inscenacija; $u$ takvom je interijeru organizacija prostora fiksna, a subjekt, $u$ prostoru koji ne postoji, dogovara s fotografom samo vrstu poze i geste. U nekoj vrsti zamrznute poze neodređena trajanja, subjekt je doslovce izložen objektivu. Za (kasnijeg) promatrača neće biti iznenađenja, jer ono što fotografija želi reći (spectrum) jest jedna režirana evidencija protagonista 
u takvoj vrsti "uniforme relikta". Ono što je evidentno jest u "naravi Fotografije da se temelji na pozi" (Ibid. 99). Iz same poze tijela oblikuje se vrlo jasna sigurnosna granica između objekta u uniformi i okoline, uglavnom studijskoga imaginarnog pejzaža, u koji je ušao prikazati se i ovjekovječiti kao uspravan, čvrstog stava, besprijekorno zakopčan, tijela koje je ukrućeno, u ulozi uniformiranog "vojnika relikta".

Taj vojnik nije u sadašnjem vremenu nego izvan vremena što uniforma potvrđuje jer je to i dalje romantični koncept uniforme i "predstavlja vanvremenski mentalni tip uzvisivanja zemaljskog u apsolutno" (Grubačić 1982:15). "I ovde se romantika definiše kao

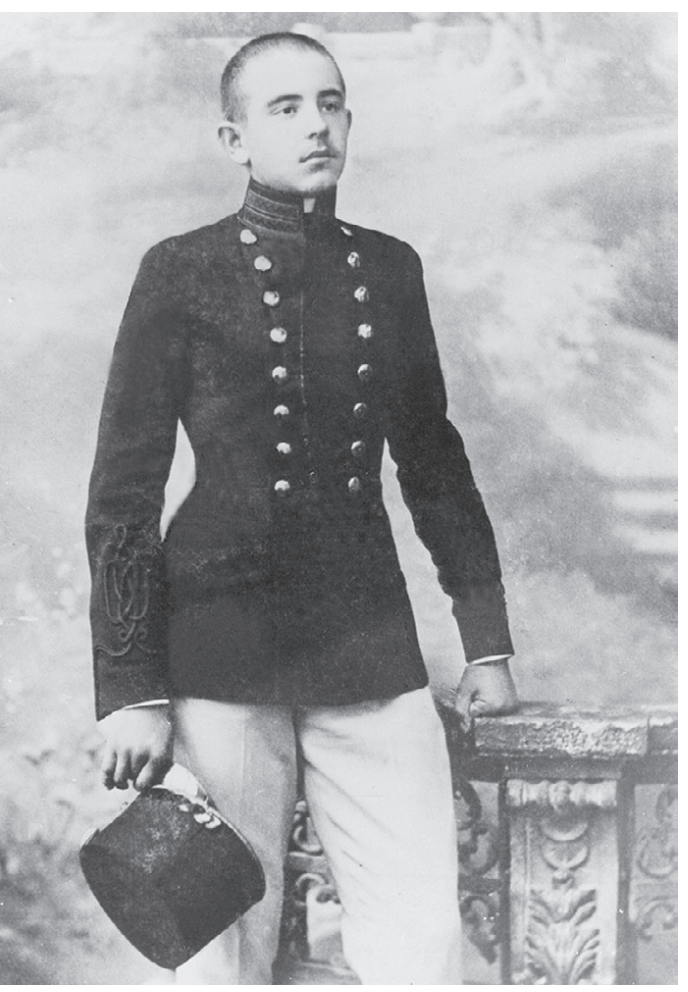

Slika 3: Miroslav Krleža kao pitomac u kadetskoj školi Ludoviceum, fotograf: nepoznat, 1911. (vl. Muzej grada Zagreba, Memorijalni prostor Miroslava i Bele Krleža, Zagreb) privid i kostimiranje izumrlog, (...) u temperiranom životu otmene površnosti” (Ibid. 20). Ta površnost, o kojoj govori Grubačić, precizno je elaborirana ornamentikom koja zaposjeda površinu uniforme s kićankama, zlatovezom, gajtanima, sujtaš trakama, gumbima, pomponima i resama, odlikovanjima, koji zajedno grade komplicirane ornamentalne uzorke koji sređuju strah od praznine površine. Ovaj razvijeni uzorak svoje podrijetlo i čežnju nalazi u husarskim historicističkim oblicima dekoracije, a kojima se često nadodaju dekoracije za "romantična" herojstva - medalje i ordeni, i predstavlja bogato i minuciozno razvedeni narativ vojničkoga duhovnog ustrojstva. Ornamentalna površina zauzeta je vijugama i ukrasima, kao manifestacija dominacije detalja koji metodom pars pro toto govore o cjelini. U trećem dijelu trilogije Mjesečari, Broch ubacuje esej Raspad vrijednosti koji problematizira pitanje stila i 
estetike ornamenta koji zauzima površinu kao dijela "unutarnje logike neke građevine (...) i u krugu te logike ornament je samo poslednji, diferencijalni izraz u malome za jedinstvenu i objedinjavajuću osnovnu misao celine" (Broh 1982b:59).

\section{FOTOGRAFIJA U FUNKCIJI EVIDENTIRANJA STVARNOSTI}

Već zarana fotograf izlazi iz studija na mjesta događanja radi snimanja fotografija ostavljajući zapis o evidenciji događaja u nekom vremenu kao dokazu "da se to dogodilo". Fotografija predstavlja samo trag toga trenutka koji svaki put ponovno ustanovljuje prolaznost vremena. "Važno je da snimka posjeduje snagu ustanovljivanja, i da se ustanovljujuće Fotografije ne odnose na predmet, nego na vrijeme" (Barthes 2003:111).

U ranijoj fazi razvoja, brojne tehnološke prepreke, veličina i težina kamere, nezgrapnost fotografskog alata, sporost proizvodnje negativa i fotografije, kao i komplicirane tehnike reprodukcije (načinjene "prema fotografiji" uz pomoć drvoreza, bakroreza ili litografije) uvjetovale su da fotografije budu rađene primarno za privatne albume ili izložbene namjere, a manje za reprodukciju u tiskanim medijima.

Izazovi ratnih događaja stvaraju prve ratne fotografe izvjestitelje (Roger Fenton, Alexander Gardner, Mathew B. Brady) čije fotografije, zbog složenih načina reprodukcije u tiskanim medijima, dopiru do javnosti s priličnim zakašnjenjem, gubeći auru "svježe" novosti.

Osim toga, ekspozicija mora trajati od tri do dvadeset sekundi (...) Nakon tri mjeseca mukotrpnoga rada Fenton se vraća u London $\mathrm{s}$ otprilike 360 klišea. Dobivene fotografije dale su prilično iskrivljenu predodžbu o ratu jer prikazuju isključivo dobro režirane skupine vojnika iza vatrene linije" (Freund 1981:101).

Dugo vremena trebat će da se razvije prikladna tehnologija koja će fotografije ustoličiti kao brze prijenosnike najnovijih vijesti. Osim poteškoća u razvoju fotografskih i tiskarskih tehnologija, javljaju se različiti oblici cenzure kojima se uređuju i ograničavaju slobodna reproduciranja fotografija, čime se otežava dostupnost i veća javna vidljivost fotografskih slika. Te su fotografije ipak nalazile put do tiskanih medija proizvodeći učinak šoka s obzirom na dramatičnost prikazanih događaja. Fotografije iz 
ove rane faze "fotografskog izvještavanja" u više slučajeva otvaraju pitanja o autentičnosti snimljenog događaja što će utjecati na vjerodostojnost i stvarnu dokumentarnu istinitost fotografske slike. Ostaje tako i danas neriješeno pitanje fotografija Alexandera Gardnera jer neke fotografije pokazuju da su naknadnim dovođenjem tijela mrtvih vojnika pred objektiv zapravo bile režirane. Uz to, preferirani su predmeti snimanja pripadnici vojne elite, zatim lokalni vojnici u egzotičnim uniformama s naznakama folklorne odjeće, kao i druge egzotične antropološke teme, a rjeđe sami vojnici u uniformama. Proizvodnja fotografija, mogućnost upotrebe negativa za multiplikaciju, predstavlja velik potencijal komunikacijske razine fotografske slike, njezinu dostupnost $i$ javnost. No prava snaga poruke ovisit će o razvoju medija i tehnika reprodukcije u tiskanim medijima.

Iako je trebalo vremena, "mehanizacija reprodukcije (...) široko su otvorila vrata ulasku fotografije u štampu. Tek je 1904. godine londonski Daily Mirror počeo svoje stranice ilustrirati isključivo fotografijama da bi njegov primjer slijedio njujorški Illustrated Daily News, i to tek 1918" (Ibid. 100). Ta mogućnost da se u medije uvede fotografija koja time potiskuje tekstualnu deskriptivnost, potvrđuje snagu fotografije kao prijenosnika poruke koja silno približava daleke prostore i već prošle događaje. "Time što se pogled širi, svijet se sužava" (Ibid. 99-100). Razvitak tehnologija snimanja, proizvodnje fotografije, brza priprema za tisak, industrijska metoda masovne proizvodnje i difuzije tiskanih medija osigurat će brzu dostupnost, javnost i komunikativnost fotografske poruke u nevidljivim razmjerima. "Prošlo je vrijeme stvarno postalo dostupno kao masovna roba" (Mirzoeff 1999:71).

\section{VELIKI RAT - REPREZENTACIJSKE SLIKE UNIFORMI}

Prvi svjetski rat postaje neiscrpan izvor za foto-žurnalistički medijski posredovani vizualni materijal. Tiskani mediji postaju presudno utjecajni na oblikovanje i prezentiranje vizualne vizije svijeta i života. Uz razvoj tehnologije, proizvodnje i reprodukcije fotografske slike, razvija se i novi

\footnotetext{
${ }^{5}$ Za ovo istraživanje korištene su fotografije iz dva fotoalbuma anonimnog sudionika Velikog rata, a koje nude privatni pogled na ratna zbivanja ilustrirajući promjenu doživljaja ratne situacije. Budući da dokumentiraju život uniformiranih vojnika u ratnim uvjetima, predstavljaju dragocjen dokumentaristički materijal za daljnja istraživanja.
} 
profil fotografa - reportera koji se "sastojao u tome da snimi pojedinačne fotografije kojima će se popratiti neka vijest" (Freund 1981:105). Te su vijesti kondenzirane slikovne informacije sada namijenjene dnevnom tisku i predstavljaju fotoreporterov "subjektivni kadar" kao neki oblik dokumentarnog realizma. "Pisana je riječ apstraktna, no slika je konkretan odraz svijeta u kojem živimo. Zamjenjivanjem individualnog portreta kolektivnim, fotografija inaugurira vizualne masovne medije.” (Ibid. 100) To rezultira proizvodnjom mnogo veće količine reportažnih profesionalnih, ali i amaterskih privatnih fotografija, koje nisu planirane, režirane, i stoga predstavljaju vjerodostojni dokumentarni materijal.

Svakodnevica postaje zasuta silnom količinom fotografija. Osim prisutnosti u dnevnim tiskovinama, velika količina fotografija amaterskog je podrijetla, kako u privatnom tako i javnom životu. Fotografije cirkuliraju kao privatni prijenosnici memorije ("za uspomenu"), ali i kao dokument o pripadanju aktivnim vojnim postrojbama i sudjelovanju na bojišnicama. Tomu je pomogla proizvodnja manjih fotografskih aparata (Vest Pocket Kodak patentiran 1902. godine) kojima su vojnici uglavnom potajno dokumentirali ratne doživljaje koji postaju dio privatnih albuma. Naime, pravo snimanja vojnih operacija pripadala je samo akreditiranim ratnim fotografima, uz jaku kontrolu i cenzuru koja je bila propisana. Amaterske fotografije uglavnom bilježe vojnički život, a rjeđe same vojne akcije. ${ }^{5}$

Prvi svjetski rat donijet će velike promjene u izgledu i funkciji vojne uniforme, mada traženja dobrih rješenja funkcionalnosti uniforme i začetke masovne proizvodnje dugujemo sukobima i ratovima u 19. stoljeću (Krimski rat, Američki građanski rat, Burski ratovi itd.). Masovna proizvodnja odjevne industrije ekspandirat će u drugoj polovini 19. stoljeća $\mathrm{i}$ to na iskustvima industrije vojnih uniformi koja je prva uspostavila proizvodne standarde, krojeve, oblike, mjerne razmjernike tijela po veličinama: time se proizvodnja uniformi omasovljuje i depersonalizira postajući anonimni serijski proizvod. Treba spomenuti kako je ratovanje Engleza u Indiji doprinijelo da se izbriše šarenilo dotadašnjih uniformi u živim bojama uvodeći novu i univerzalnu, do danas važeću vojničku kaki boju. To je riječ iz Urdu jezika, a označava boju vojničkog materijala za uniforme, kao sivu blatnu boju, kod nas uvriježenu kao smb - sivomaslinasta boja, a čije izvedenice i dandanas označavaju boju vojnih kopnenih uniformi. Osim 
masovnosti i potrebe za ekonomičnošću proizvodnje koja je glavni motiv, univerzalna je boja $u$ isto vrijeme našla opravdanje u vojnom zahtjevu za mimikrijskom prilagodbom vojnom terenu i potrebi smanjene vidljivosti.

Masovna industrijska proizvodnja početkom 20. stoljeća visoko je organizirana i razvijena, uz daljnje širenje i omasovljenje u funkciji nadolazećega Prvog svjetskog rata. Veliki rat, osim naglo povećanih količina, predstavlja veliku promjenu dotadašnjih proizvodnih i simboličnih vrijednosti vojnih uniformi.

Dok pratimo nestanak jedne vrste predratnoga romantičnog koncepta uniforme, pojavljuju se istraživanja i rješenja za nove funkcionalno oblikovane uniforme. Taj oproštaj s "raspadnutim vrijednostima" bilježi i Gombrowiczu Posmrtnoj autobiografiji kazujući o iščezavanju dotadašnjeg osjećanja uniforme, a time i jednog načina mišljenja koje se sada zamjenjuje novim pristupom, "slobodom duha", jer dolazi do "drobljenja monarških tronova i krutih ovratnika, brkova i 'časnih' predrasuda, slobode tijela što se miješa sa slobodom duha, pogrom žaketa, lakiranih cipela” (Gombrowicz 2014:35).

Preko postupnog nestanka koncepta pojedinačne, studijske fotografije pratimo nestanak (predratnoga) romantičnog koncepta "uniforme relikta" uz proces desemantizacije jedne vrste kodiranja (individualnost, pojedinačni ručni proizvod, simbolika jasnih boja, ornamentalni pristup) u prilog uvođenju (ratnog) koncepta novih vrijednosti, zahuktavanju industrijalizacije, masovne proizvodnje, time i procesu resemantizacije (masovnost, serijska proizvodnja, standardizacija, nestanak boje i uvođenje mimikrijske kaki boje, kao dijelu funkcionalizma industrijskog mišljenja).

U novim ratnim uvjetima, uniforma mora funkcionirati u stvarnosti kakva je na bojnom polju, umjesto vertikalnog stava u fotografskom studiju počet će dominirati ležeći položaj, horizontala: netko je rekao da je Veliki rat bio prvi koji se vodio horizontalno - u rovovima.

Nova ratna uniforma nije mišljena za individualno tijelo nego za mase vojnika koji uniformu i opremu dobivaju činom mobilizacije kao sledovanje. Budući da veličina, izgled i mimikrija velikog broja anonimnih vojnika trebaju biti u funkciji nepredvidljivog ratovanja velike i složene ratne mašinerije, dizajn uniformi precizno je studiran proces praćen propisima masovne upotrebe i potrošnje: uniforma postaje ready made 
popraćen propisnicima funkcioniranja masovne ratne industrije, bez ili s vrlo malo mogućnosti intervencije u vlastiti vojnički izgled, a kojim se trebala pokazati profesionalna pripadnost ratno organiziranoj mašineriji.

U Austro-Ugarskoj dolazi do standardizacije uniforme 1908. godine (M1908), uglavnom sivomaslinaste boje, a pripadnost rodu označavala se sitnim kolorističkim detaljima na ovratniku. Suočeni s novim izgledom u novoj vrsti "štukastosivih" uniformi, mobilizirani vojnici često iskazuju konflikt između prije stvorene predodžbe o izgledu i zahtjevima nove realnosti.

Tako Stjepan Kolander iz Zagreba u svojim ratnim Dnevnicima iz 1914. godine doživljava uniformu ("sivo ratno odijelo") kao nešto istina "ukusno, na mješta preširoko":

Dana 26. srpnja [1914.] bude proglašena djelomična mobilizacija. U $10 \mathrm{~s}$ jutrom dizali smo sivo ratno odijelo, te sam već poslije podne u njemu izišao. Sve bje ukusno, na mješta preširoko. Žute cipele iz 'jahtovina' kože (...) Dobio sam slijedeće stvari: Sive hlače, do koljena stisnute, gornji dio širok. Sivi haljinac, siva kapa, žute cipele (...) remen (...) Kabanica s postavom (...) 2 para nova rublja ljetne i zimske, trbušnjak, rukavice, 2 para zimskih i ljetnih obojka... sve oko 30 kg težine." (Kolander 1914:1).

Robert Graves u autobiografskom romanu Zbogom svemu tom o sebi kao vojniku u Prvom svjetskom ratu navodi da "ne nalikuje vojniku (...) Rekao je da me neće poslati u Francusku sve dok potpuno ne sredim svoju garderobu i ne počnem izgledati kao vojnik - izvještaj zapovjednika moje satnije o meni glasio je 'ne nalikuje vojniku'" (Graves 2010:79).

Zanimljivo je da Robert Graves također nabraja sve dijelove uniforme i popratnog pribora na sličan način kao i Stjepan Kolander, iz čega se može vidjeti da su pravila uniforme i izgleda ujednačena, a ukupna težina opreme također je oko $30 \mathrm{~kg}$ : "Sastavio sam popis njihovog osnovnog tereta koji teži blizu trideset kila" (Ibid. 116) .

Ujednačavanje uniformi i izgleda istiskuje vidljivost pojedinca $u$ korist vidljivosti grupe: slika prikazuje masovne situacije, a dokumentarnost fotografija postaje vjerodostojna, nerežirana, prikazujući trenutke "realnog života" - raskopčane uniforme, nemar, sjedenje na zemlji, pripadanje ratnom zadatku, a ne poziranju: 


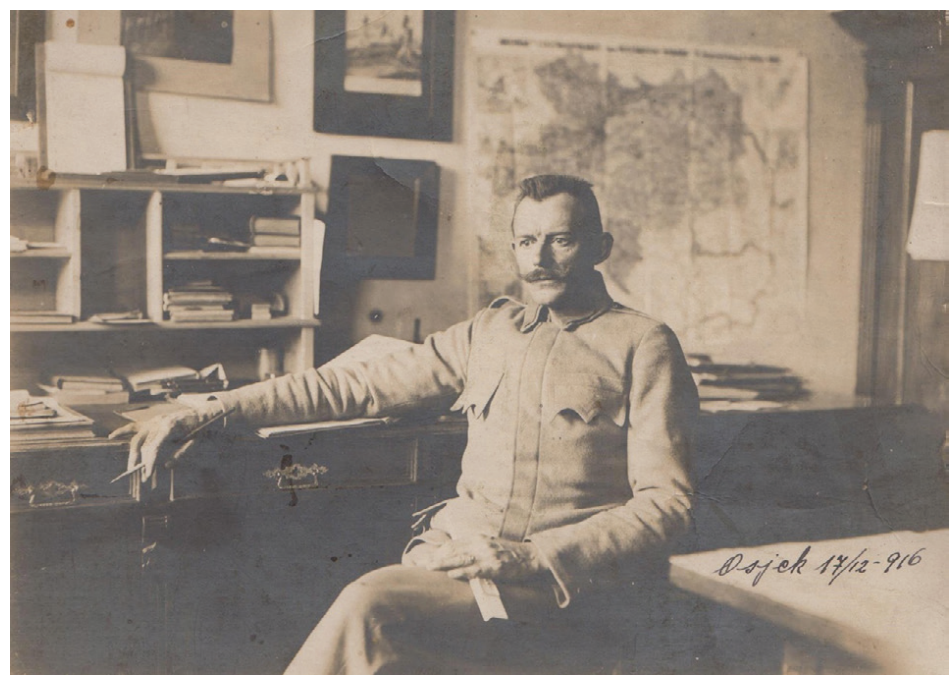

Slika 4: Vojnik u uniformi, fotograf: nepoznat, Osijek, 1916.

Započeo je (...) općenitim optužbama kako je u posljednje vrijeme unutar bojne primijetio mnogo zakona nemarnosti - ljude s otkopčanim džepovima te one koji doslovno hodaju seoskom ulicom s rukama u džepovima hlača s neulaštenim čizmama (Ibid. 193).

Uniforma više nije čvrst i jasan okvir koji kontrolira tijelo nego je tijelo pokrenuto i određeno dinamikom promjenjivosti situacija. Uniforma funkcionira sukladno situaciji i zadaći. Lišena je dekorativnosti, površina je reducirana, uglavnom označena s četiri funkcionalna džepa i skromnom oznakom vojničkog ranga. Bluza je često raskopčana, hlače su komotne, osiguravaju pokretljivost. Jedino što dominira jest monokromna kaki boja uniforme koja homogenizira sliku grupe i naglašava funkciju mimikrije.

Ovakve slike nemarnog izgleda rijetko nalazimo vidljivima u tiskanim medijima gdje dominiraju pomno odabrane i uređene fotografije s prikazima grupa vojnika na bojišnici. Privatne ratne fotografije u javnosti ostaju uglavnom nevidljive jer je medijska slika bila podložna strateškim postupcima cenzure i uređivanja, a sve $u$ funkciji ratne propagande.

Povećavaju se broj fotoreportera i proizvodnja komercijalne fotožurnalističke slike, uz jačanje snage i "carstva medija" (Blom 2015:13), pa time vidljivost i dostupnost informacije preko fotografske slike dobiva posebnu važnost. Ono što možemo čitati na fotografijama odgovara tekstu u pisanim dokumentima - na jednak način fotografija, tj. fotografski objektiv 
promatra, registrira i prenosi autentične situacije na otvorenom prostoru bojišnice, u rovovima, po danu i po noći.

Putem novih masovnih tiskanih medija, izravno s bojišnice, fotografije neviđenom brzinom dopiru u javnost u dnevnom ritmu i primaju se kao važni čimbenici nove i drugačije konstrukcije stvarnosti. Za rekonstrukciju vizualne situacije i čitanje slike iz današnje perspektive potrebno je uspostaviti novi pogled na fotografsku sliku. Fotograf i predmet snimanja, kao i njihovi odnosi, suštinski su se promijenili, donoseći fotografskim slikama nove reprezentacijske modele stvarnosti.

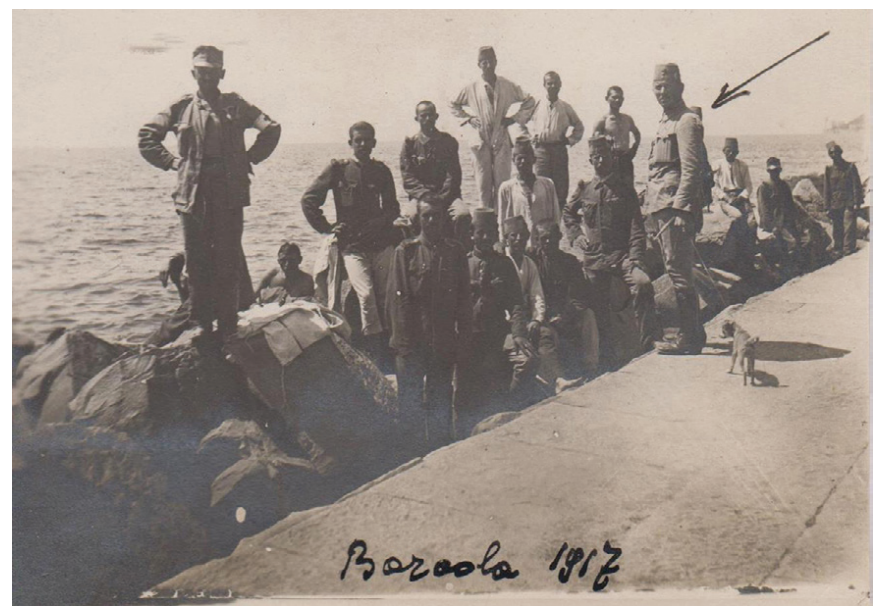

Slika 5: Vojnici na plaži Barcola, Trst, album, fotograf: nepoznat, 1917.

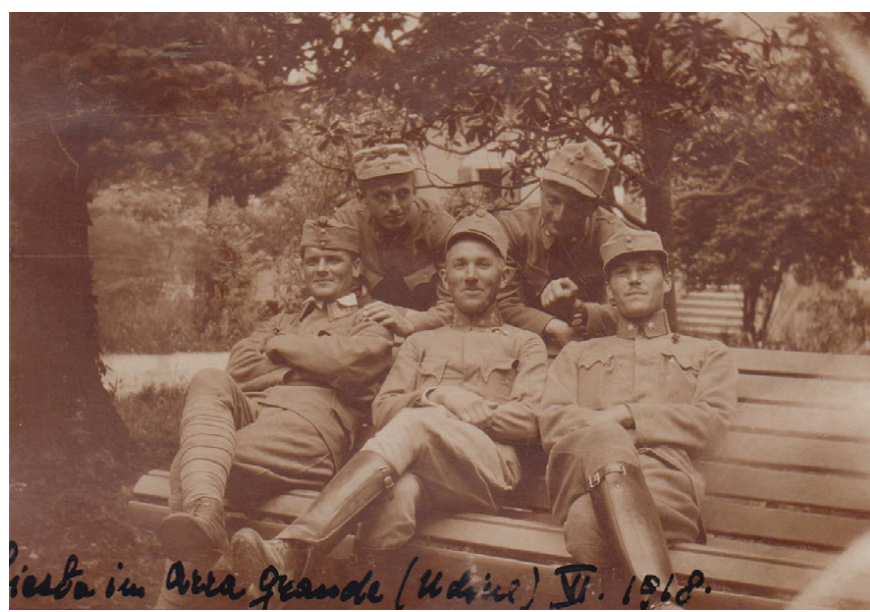

Slika 6: Vojnici u uniformama, Udine, album, fotograf: nepoznat, 1917. 


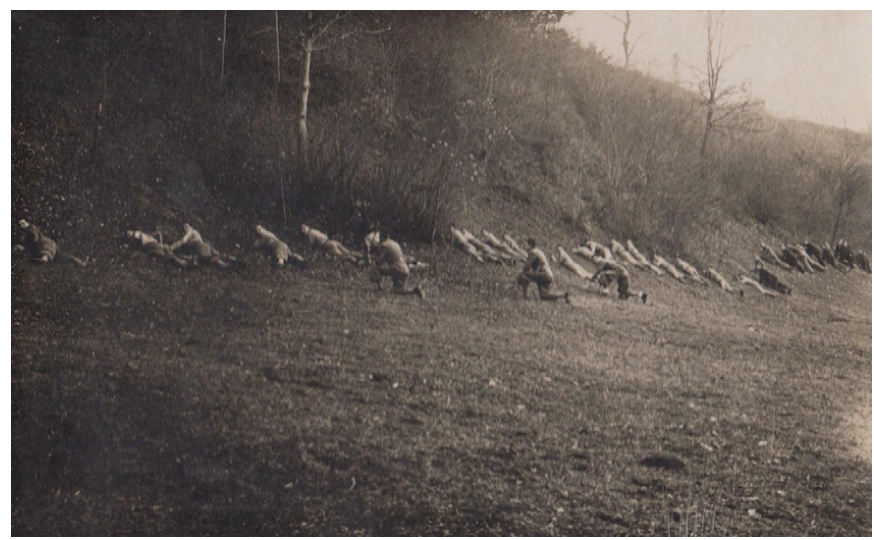

Slika 7: Vojnici na bojišnici, album, fotograf: nepoznat, oko 1917.

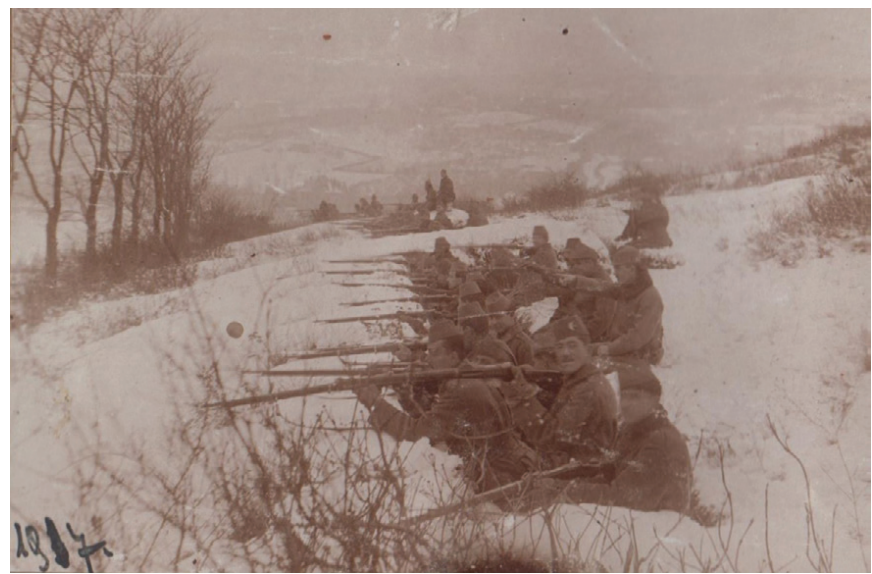

Slika 8: Vojnici na bojišnici, album, fotograf: nepoznat, 1917.

\section{ZAKLJUČAK}

Povijest je iznjedrila uniforme kao važan tekst o ideološkom, vojnički označenom tijelu i duhu i time značenjskim promjenama vidljivima $u$ širem društvenom tijelu. Kao ideološka ekstenzija vojne, militarističke ideje, uniforma ujednačava, negira i depersonalizira protagonista. Razvoj reprezentacije uniforme kretao se od pojedinačne, statične, salonske (studijske) fotografije kao romantičnog teksta o pojedincu, prema bilježenju i reprezentaciji homogenizirane kolektivne slike. Razvoj militarizacije vidimo u zamahu industrijske masovne proizvodnje standardiziranih 
uniformi. S druge strane, usporedno pratimo razvoj tehničkih pretpostavki za povećavanje proizvodnje i reprodukcije reprezentacijske fotografske slike, kao i povećanje medijske dostupnosti takve slike. Time se jedan romantični koncept studijske slike istiskuje, a to se mjesto u stvarnosti, kao i slikovnoj reprezentaciji, zamjenjuje realističnim slikama događaja koje time evidentiraju i potvrđuju da "upravo to je bilo" (Barthes 2003:124).

Fotografija, naravno, nikada nije neutralna: ona evidentira i prenosi na neki čudan način mogućnost istine. U slučaju Velikog rata, fotografije preko slika uniformi omogućuju susret i reprezentaciju različitih aspekata (moguće) istine. Reprezentirajući kompleksni sustav kodiranosti, ona omogućuje usporedbe dviju kontrastno različitih retorika slike, a time dviju različitih istina o značenju uniformi u vremenu tako brzih i velikih promjena: umjesto singularnosti i statičnosti romantičarskog koncepta, nova fotografska slika čini vidljivim reprezentaciju masovnosti uniformi u kontekstu dinamičnih promjena stvarnosti.

Pokazat će se da je Veliki rat donio raspad i nestanak jedne vrste uniforme i njezino povlačenje u protokolarne ceremonijske situacije, a uveo sasvim drugačiju vrstu vojne funkcionalne uniforme. Budući da i sama reprezentira, njezina fotografska reprezentacija predstavlja retoričnost otvorenu novom čitanju.

\section{LITERATURA}

ARALICA, Tomislav i Višeslav ARALICA. 1996. Hrvatski ratnici kroz stoljeća. Zagreb: Znanje.

BARTHES, Roland. 2003. Svijetla komora: bilješka o fotografiji. Zagreb: Izdanja Antibarbarus.

BENJAMIN, Walter. 1986. Estetički ogledi. Zagreb: Školska knjiga.

BLOM, Philipp. 2015. Vrtoglave godine 1900.-1914. Zagreb: Fraktura.

BONAMI, Francesco, Maria Luisa FRISA i Stefano TONCHI, ur. 2000. Uniform: Order and Disorder. Milano: Edizioni Charta.

BROH, Herman [i. e. Hermann BROCH]. 1982a. Mesečari, sv. I-II. Beograd. Nolit.

BROH, Herman [i. e. Hermann BROCH]. 1982b. Mesečari, sv. III. Beograd. Nolit.

CRAIK, Jennifer. 2005. Uniforms Exposed: From Conformity to Transgression. Oxford - New York: Berg.

CRANE, Diana. 2000. Fashion and Its Social Agenda. Chicago: University of Chicago Press. 
CVITAN-ČERNELIĆ, Mirna, Djurdja BARTLETT i Ante Tonči VLADISLAVIĆ, ur. 2002. Moda: povijest, sociologija i teorija mode. Zagreb: Školska knjiga.

DUNN, Bill. 2009. Uniforms. London: Laurence King Publishing.

ENGLISH, Bonnie. 2013. A Cultural History of Fashion in the 20th and 21st Centuries: From Catwalk to Sidewalk. London - New York: Bloomsbury Academic.

FREUND, Gisèle. 1981. Fotografija i društvo. Zagreb: Grafički zavod Hrvatske.

FRIZOT, Michel, ur. 1998. A New History of Photography. Köln: Könemann.

GOMBROWICZ, Witold. 2014. Posmrtna autobiografija. Zagreb: Fraktura.

GRAVES, Robert. 2010. Zbogom svemu tom. Zagreb: Sandorf.

GRUBAČIĆ, Slobodan. 1982. "Predgovor. Metodična konstrukcija polihistorijskog romana". U Herman BROH [i. e. Hermann BROCH], Mesečari, sv. I-II. Beograd: Nolit, 15-20.

JEFFREY, Ian. 1981. Photography: A Concise History. London: Thames \& Hudson.

KOLANDER, Stjepan. 1914. Dnevnik, I.-XX. Bez ruma nema šturma! Prvi svjetski rat kroz Dnevnik Stjepana Kolandera. Zagreb: Hrvatski povijesni muzej. http://www. bezrumanemasturma.hismus.hr/index.html (pristup 28. 4. 2016.).

MARIEN, Mary Warner. 2002. Photography: A Cultural History. London: Laurence King Publishing.

MIRZOEFF, Nicholas. 1999. An Introduction to Visual Culture. London - New York: Routledge.

NEUBAUER, Hendrik. 1997. 60 Years of Photojournalism: Black Star. Köln: Könemann.

ORVELL, Miles. 2003. American Photography. Oxford - New York: Oxford University Press.

PERROT, Philippe. 1994. Fashioning the Bourgeoisie: A History of Clothing in the Nineteenth Century. Princeton, NJ: Princeton University Press.

PINNEY, Christopher. 2011. Photography and Anthropology. London: Reaktion Books.

SENNETT, Richard. 1989. Nestanak javnog čovjeka. Zagreb: Naprijed.

SONTAG, Susan. 1979. On Photography. London: Penguin Books.

THOMPSON, Jerry L. 2013. Why Photography Matters. Cambridge, MA: The MIT Press.

VINKEN, Barbara. 2005. Fashion Zeitgeist: Trends and Cycles in the Fashion System. Oxford - New York: Berg.

WADDELL, Gavin. 2004. How Fashion Works: Couture, Ready-to-Wear and mass Production. Oxford: Blackwell.

WELLS, Liz, ur. 1996. Photography: A Critical Introduction. London - New York: Routledge. 
WELLS, Liz, ur. 2003. The Photography reader. London - New York: Routledge.

WILSON, Elizabeth. 2003. Adorned in Dreams: Fashion and Modernity. New Brunswick, NJ: Rutgers University Press.

Ante Tonči Vladislavić

\section{GREAT WAR - GREAT CHANGES: READING THE CHANGING IMAGE OF THE MILITARY UNIFORM}

This paper deals with the appearance and representation of military uniforms, which became an inevitable and standardized wartime feature during WWI. Uniforms became an important part not only for wartime, but also as an overall clothing appearance. The changes in the military uniform style displaced the previous vision of the uniform and its encoding, thus saturating the semantic space with new codes, which can be read on the level of the uniform as an object, but even more so on the basis of the photographic image rhetoric. The progress of industrialization and mass production of standardized military uniforms coincided with the emergence of the industry of creating and reproducing images (i.e. photography) in the printed media, so all information about the changes in uniform styles can be read as the changes in the encoding of the photographic representation. The paper aims to shed light on the changes that took place in the development of the military uniform as an object and the changes of its encoding within the representation of the photographic image, and it is a part of a broader research, which is still underway, focused on military uniform, appearance, meaning as forms of clothing and representational image. The Centre for fashion and clothing research is doing research under the project "Male manifest: Construction of stereotypes and representations of 'male fantasies' clothing, appearance, typology, and forms of social impact of male power during socialist Yugoslavia". The project researches and problematizes the relationship between fashion and clothing and a significant part of it is dedicated to the establishment and representation of the male military uniform - with special focus on the visual rhetoric of a photographic image.

Keywords: WWI, military uniforms, photographic image rhetoric, representation in the photographic image

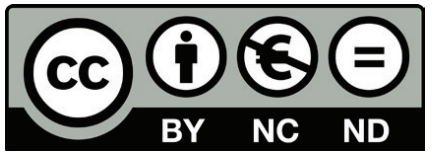

Articles published in this journal are Open Access and can be distributed under the terms and conditions of the Creative Commons license Attribution-NonCommercial-NoDerivatives 4.0 (http://creativecommons.org/licenses/by-nc-nd/4.0/) 